\title{
TEACHERS' VIEW ON KSSR MATHEMATICS DOCUMENT STANDARD OF CURRICULUM
}

\author{
${ }^{1}$ Ikhsan Othman, ${ }^{2}$ Wan Azimah Wan Kadir \\ ${ }^{1,2}$ Faculty of Human Development \\ Sultan Idris Education University
}

Received : 29 September 2017; Accepted : 6 November 2017; Published : 15 December 2017

\begin{abstract}
Primary School Standard Curriculum (KSSR being its acronym in Malay Language) was implemented since 2011 involving all subjects including Mathematics. Discussion in this paper is related to a study on teachers' view on the syllabus used for KSSR Mathematics limited to level 1 primary school Mathematics. The study aimed to identify teachers' view on the curriculum for the aspects of its objectives, learning experiences, organization of learning experiences and learning assessment. A four Likert scale questionnaire was built and used in the study. A total of 92 respondents from 58 primary schools were involved comprising of 44 males and 48 females teachers. Data were analyzed using SPSS version 20.0. The results of the study showed that teachers' level of agreement on the curriculum was high for the aspect of objectives (mean score 3.396, SD 0.296); learning experiences (mean score 3.391, SD 0.286); organization of learning experiences (mean score of 3.452, SD 0.241); and learning assessment (mean score 3.376, SD 0.281). Analysis of t-test found that there was no significant difference at $\mathrm{p} \leq .05$ for teachers' level of agreement between male teachers and female teachers for the mentioned aspects. Remark from this study is that; document standard of curriculum for KSSR Mathematics level 1 in Malaysian primary school is said to be suitable from teachers' perspective. Studies involving larger samples and various other aspects of the curriculum should be done to get better and more accurate results.
\end{abstract}

Keywords KSSR Mathematics, Document Standard Of Curriculum.

\begin{abstract}
Abstrak
Kurikulum Standard Sekolah Rendah (KSSR) telah dilaksanakan sejak tahun 2011) melibatkan semua mata pelajaran termasuk Matematik. Perbincangan dalam kertas kerja ini adalah berkaitan dengan kajian mengenai pandangan guru tentang sukatan pelajaran yang digunakan dalam Matematik KSSR terbatas kepada Matematik sekolah rendah tahap 1. Kajian bertujuan untuk mengenal pasti pandangan guru terhadap kurikulum bagi aspek objektif, pengalaman pembelajaran, organisasi pengalaman pembelajaran dan penilaian pembelajaran. Soal selidik empat skala Likert telah dibina dan digunakan dalam kajian ini. Seramai 92 responden dari 58 buah sekolah rendah terlibat dan terdiri daripada 44 guru lelaki dan 48 guru perempuan. Data dianalisis menggunakan perisian SPSS versi 20.0.
\end{abstract}


Keputusan kajian menunjukkan bahawa tahap persetujuan guru terhadap kurikulum tersebut adalah tinggi bagi aspek objektif (skor min 3.396, SP 0.296); pengalaman pembelajaran (skor min 3.391, SP 0.286); organisasi pengalaman pembelajaran (min skor 3.452, SD 0.241); dan penilaian pembelajaran (skor min 3.376, SD 0.281). Analisis ujian-t mendapati tidak terdapat perbezaan yang signifikan pada $\mathrm{p} \leq .05$ tahap persetujun antara guru lelaki dan guru perempuan bagi aspek-aspek tersebut. Rumusan daripada kajian ini ialah; dokumen standard kurikulum Matematik KSSR tahap 1 sekolah rendah di Malaysia dikatakan sesuai daripada perspektif guru. Kajian yang melibatkan sampel yang lebih besar serta lain-lain aspek kurikulum perlu dilakukan untuk mendapatkan keputusan yang lebih baik dan lebih tepat.

Kata kunci KSSR Matematics, Dokumen Standard Kurikulum.

\section{INTRODUCTION}

Malaysia Ministry of Education through a circular No. 11/2010 dated October 14, 2010, ordered that Primary School Standard Curriculum (KSSR being its acronym in Malay Language) should be implemented in all Malaysian primary schools by January 2011. The implementation of KSSR was first announced on June 2010. The implementation was in the stages starting with pupils in Year 1 in 2011 to finally pupils in Year 6 in 2016. Transformation from the former Integrated Primary School Curriculum (KBSR being its acronym in Malay Language) to KSSR is a form of holistic transformation of the primary school curriculum. The transformation is in parallel with the second National Key Results Areas (NKRA) which was announce by Malaysia Prime Minister (Curriculum Development Centre (2012). It is to ensure all primary school pupils have the achievement in basic skills after they have undergone six years formal primary schooling.

The transformation involves the transformation of organization; content; pedagogy; time allocation; assessment methods of learning; teaching and learning materials; and curriculum management (Curriculum Development Centre, 2010b). KSSR was designed to ensure school pupils are provided with relevant knowledges, skills and values to enhanced their capablity in facing the 21 st century challenges which will keep on changing. Generally, KSSR intends to produce a balanced human being with creative, critical and innovative thinking.

By maintaining proficiency in reading, writing and arithmetic $(3 \mathrm{M})$; value added in KSSR compare to the former Integrated Primary School Curriculum (KBSR being its acronym in Malay Language) is reasoning skills. The skills makes $3 \mathrm{M}$ become 4M. Reasoning skills promote pupils capable to make decisions based on common sense and logic. In addition to the content of the subject, there are also elements that are integrated across curriculum such as creativity and innovation; entrepreneurship; and skills of information and communication technology (ICT). Further more, students are expected to be able to communicate with multiple languages other than Malay language; being patriotic; ethical; self confidence; appreciative; practice the spirit of unity; and love the country. 
Continuous trainings are given to schools teachers to ensure the process of students' learning and facilitating in KSSR run smooth and effectively. KSSR generally confirms variety of approaches for students' learning and facilitating that bring more impacts on students. Teacher-centered learning has shifted to hands on learning such as inquiry; project-based learning; contextual learning; mastery learning; and open classroom learning which are indispensable for students undergoing the process of students' learning and facilitating more interesting (Curriculum Development Centre, 2011). The focus is on student-centered learning which will provides spaces and opportunities for students in their learning process. The approach used should be towards a fun learning opportunity under the concept of learning is fun as well as taking into account the diversity and students multiple levels of potentials. Therefore teachers should be more creative and innovative in handling the process of students' learning and facilitation in the classroom.

In KSSR, the concept of students assessment has replaced the concept of evaluation which was implemented previously in KBSR (Malaysia Ministry of Education, 2011). KSSR Mathematics also emphasises the implementation of School Based Assessment (SBA) to ensure students' learning and facilitating more fun and not too exam-oriented. A variety of assessment methods used to enable assessment more authentic and holistic. The implementation of SBA is expected to be more meaningful and more effective. Formative assessment in SBA carries ongoing process of assessment to track pupils' progress and achievements in their learning. Follow up activities like enrichment for better pupils and remediation for weaker students are also carried out to the pupils after the assessment according to the pupils' performance to ensure pupils achieve the set standards and criterion (Curriculum Development Centre, 2011).

\section{BACKGROUND OF STUDY}

Tyler in 1949 outlined a model of curriculum. In the model, it is outlined that a curriculum should include four key elements namely objectives, learning experiences, organization of learning experiences and learning assessment. Figure 1 shows the said elements.

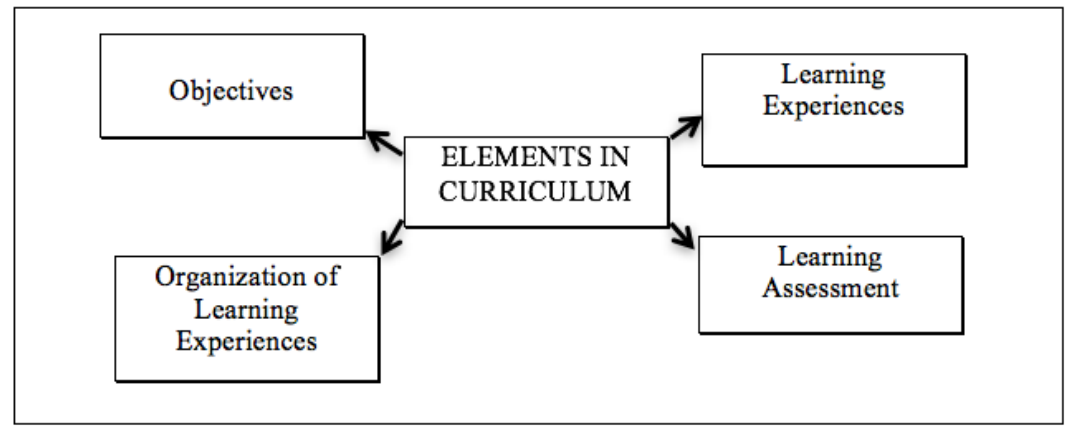

Figure 1 Tyler's Model of Curriculum (Source: Tyler, R.W. 1992). 
According to Tyler's model of curriculum, any curriculum must states its objectives to be achieved. Without any stated objective, curriculum may have 'no where to go' or 'nothing to achieve'. This will lead to problems for determining the content of the curriculum or in this context known as learning experiences. When the content of the curriculum or learning experiences had been determined, that will then be organized in such a way to be delivered smooth and effectively to students as the target group. The effective delivery of the content or learning experiences to the target group will then be assessed in the process of assessment which involves students' learning achievement of performance (Abu Bakar Nordin \& Ikhsan Othman, 2008).

For KSSR Mathematics, the curriculum emphasizes on student mastery in understanding and applying mathematical concepts and skills in various contexts besides the mastery of basic content knowledge, skills and values. Therefore KSSR Mathematics was designed with its objectives; learning experiences; organization of learning experiences; and assessment with full emphasizes of the aspects mentioned above. Of course there are ways or approaches to meet the expectation which include the use of modules in the process of students' learning and facilitating to replace the old textbooks.

\section{Problem Statement}

KSSR Mathematics is under Strand 1 category KSSR Mathematics was developed and implemented in Malaysian primary schools starting from 2011 in parallel with the implementation of KSSR. At the time this study was done, the implementation of KSSR Mathematics was considered as new development and it was at the early stages of implementation where there have not been many studies done to view the progress and the status of the transformation. Therefore, this study was aimed to know the status of the implementation of KSSR Mathematics through teachers' view on such matter.

\section{Research Objectives}

The research objectives are as follows.
a) Identify teachers' view on the objectives of KSSR Mathematics.
b) Identify teachers' view on the learning experiences in KSSR Mathematics.
c) Identify teachers' view on the organization of learning experiences in KSSR Mathematics.
d) Identify teachers' view on the assessment used in KSSR Mathematics.

\section{Research Questions}

The research questions are as follows.

a) How's teachers' view on the objectives of KSSR Mathematics?

b) How's teachers' view on the learning experiences in KSSR Mathematics?

c) How's teachers' view on the organization of learning experiences in KSSR Mathematics?

d) How's teachers' view on the learning assessment used in KSSR Mathematics? 


\section{Hypotheses}

The null hypotheses of the study are as follows.

Ho (1): There is no significant difference in teachers' view on the objectives of KSSR Mathematics by gender.

Ho (2): There is no significant difference in teachers' view on the learning experiences in KSSR Mathematics by gender.

Ho (3): There is no significant difference in teachers' view on the organization of learning experiences in KSSR Mathematics by gender.

Ho (4): There is no significant difference in teachers' view on the learning assessment used in KSSR Mathematics by gender.

\section{METHODOLOGY}

Specifically the study embarked on teachers' agreement on the document standard of curriculum for KSSR Mathematics level 1, that is KSSR Mathematics for Year 1, Year 2 and Year 3. The analysis on the documents was conducted by KSSR Mathematics teachers who have experienced in implementing the curriculum .

The study was conducted with a survey method. A questionnaire was used in the survey. The questionnaire was designed by the researchers in this study with the help of experts for internal validity. The questionnaire consists of 20 items subdivided into four subscales namely the objectives, learning experiences, organization of learning experiences and assessment. The questionnaire was pilottested and was identified to have internal consistency of $\alpha=.80$. A total of 92 experienced KSSR Mathematics teachers from 58 primary schools were involved in the study. The respondents comprised of $44(47.8 \%)$ males and $48(52.2 \%)$ female teachers. The respondents have responded to each item based on four Likert scale that was 1 (Strongly Disagree), 2 (Disagree), 3 (Agree) and 4 (Strongly Agree). Questionnaires were distributed to and collected from the respondents and collected data were analyzed.

\section{DATA ANALYSIS AND FINDINGS}

Data collected from the respondents were analyzed descriptively by calculating mean score and standard deviation for each subscale. This is to identify the level of respondents' agreement on a certain aspects. The null hypothesis were tested using independent samples t-test using SPSS version 20.0. The infrential statistical analysis were done to identify whether there was any significant difference in respondents' view by gender.

\section{Teachers' View on the Objectives of KSSR Mathematics}

Research Question (a): How's teachers'view on the objectives of KSSR Mathematics? 
Ho (1): There is no significant difference in teachers' view on the objectives of KSSR Mathematics by gender.

To answer the research question (a) analysis was done descriptively by calculating the mean and standard deviation. The findings of the analysis are shown in Table 1.

Table 1 Teachers' View on the Objectives of KSSR Mathematics.

\begin{tabular}{lccc}
\hline Category of Respondents & No. & Mean Score & $\begin{array}{c}\text { Standard Deviation } \\
(\text { SD) }\end{array}$ \\
\hline Male & 44 & 3.373 & 0.316 \\
Female & 48 & 3.417 & 0.279 \\
\hline Overall & 92 & 3.396 & 0.296 \\
\hline \multicolumn{1}{c}{ 1 (Strongly Disagree), 2 (Disagree), 3 (Agree) and 4 (Strongly Agree) }
\end{tabular}

Based on the analysis, the level of teachers' agreement on the objectives of KSSR Mathematics is at the mean score $3.396(\mathrm{SD}=0.296)$. Analysis by gender shows that male teachers' agreement mean score is $3.373(\mathrm{SD}=0316)$. Female teachers' agreement mean score is $3.417(\mathrm{SD}=0.279)$. Figure 2 shows box plots for the comparison of the mean score between male teachers' and female teachers' level of agreement on the objectives of KSSR Mathematics.

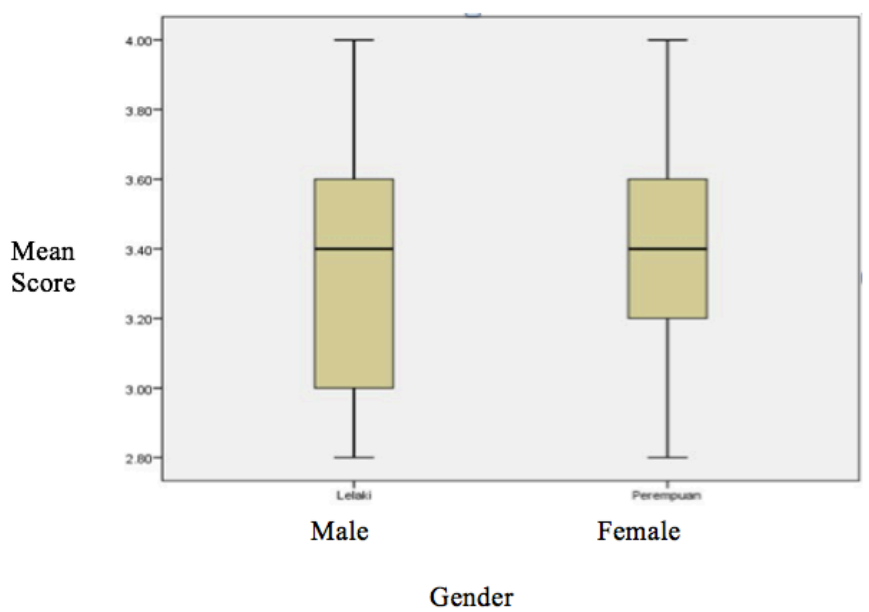

Figure 2 Mean Score Between Male Teachers' and Female Teachers' Level of Agreement on the Objectives of KSSR Mathematics.

To identify whether the difference of the mean scores between male and female teachers' agreement on the objectives of KSSR Mathematics is significant or otherwise, analysis was further done using t-test. Table 2 shows the result of the analysis. 
Table 2 Result of t-test on Mean Scores Between Male and Female Teachers' View on the Objectives of KSSR Mathematics.

\begin{tabular}{lcccc}
\hline & Levene Test & \multicolumn{4}{l}{ t-test for equality of means } & \\
\hline & Sig. & $\mathrm{t}$ & $\mathrm{df}$ & $\mathrm{P}$ \\
\hline $\begin{array}{l}\text { Equal variances assumed } \\
\begin{array}{l}\text { Equal variances not } \\
\text { assumed }\end{array}\end{array}$ & 0.349 & -0.708 & 90 & 0.481 \\
\hline
\end{tabular}

Based on Table 2, $\mathrm{t}=-0708, \mathrm{p}=0.481$, which is not significant at $\mathrm{p}<0.05$. Therefore Ho (1) which says that, there is no significant difference in teachers' view on the objectives of KSSR Mathematics by gender was failed to be rejected. In conclusion, the level of teachers' agreement on the objectives of KSSR Mathematics is high and there is no significant difference in the level of agreement between male and female teachers on on the objectives of KSSR Mathematics.

\section{Teachers' View on the Learning Experiences in KSSR Matematics}

Research Question (b): How's teachers' view on the learning experiences in KSSR Mathematics?

Ho (2): There is no significant difference in teachers' view on the learning experiences in KSSR Mathematics by gender.

To answer the research question (b) analysis was done descriptively by calculating the mean and standard deviation. The findings of the analysis are shown in Table 3.

Table 3 Teachers' View on the Learning Experiences in KSSR Mathematics

\begin{tabular}{lccc}
\hline Category of Respondents & No. & Mean Score & $\begin{array}{c}\text { Standard Deviation } \\
(\text { SD })\end{array}$ \\
\hline Male & 44 & 3.346 & 0.303 \\
Female & 48 & 3.433 & 0.265 \\
\hline Overall & 92 & 3.391 & 0.286 \\
\hline
\end{tabular}

* 1 (Strongly Disagree), 2 (Disagree), 3 (Agree) and 4 (Strongly Agree)

Result of the analysis is shown in Table 3. Based on the analysis, the level of teachers' agreement on the learning experiences in KSSR Mathematics is at the mean score $3.391(\mathrm{SD}=0.286)$. Analysis by gender shows that male teachers' agreement mean score is $3.346(\mathrm{SD}=0303)$. Female teachers' agreement mean score is 3.433 (SD $=0.265$ ). Figure 3 shows box plots for the comparison of the mean score between male teachers' and female teachers' level of agreement on the learning experiences in KSSR Mathematics. 


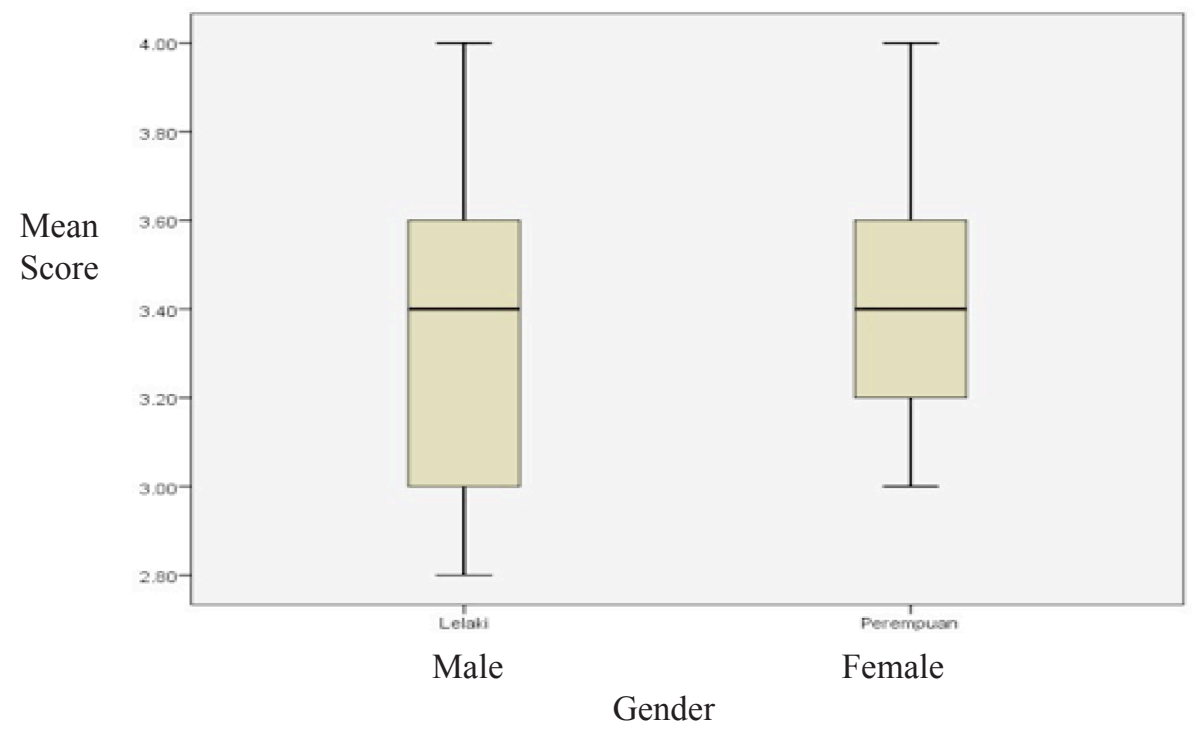

Figure 3 Mean Score Between Male Teachers' and Female Teachers' Level of Agreement on the Learning Experiences in KSSR Mathematics

To identify whether the difference of the mean scores between male and female teachers' agreement on the learning experiences in KSSR Mathematics is significant or otherwise, analysis was further done using t-test. Table 4 shows the result of the analysis.

Table 4 Result of t-test on Mean Scores Between Male and Female Teachers' View on the Learning Experiences in KSSR Mathematics

\begin{tabular}{lcccc}
\hline & Levene Test & \multicolumn{3}{c}{ t-test for equality of means } \\
\hline & Sig. & $\mathrm{t}$ & $\mathrm{Df}$ & $\mathrm{P}$ \\
\hline $\begin{array}{l}\text { Equal variances assumed } \\
\begin{array}{l}\text { Equal variances not } \\
\text { assumed }\end{array}\end{array}$ & 0.142 & -1.483 & 90 & 0.142 \\
\hline
\end{tabular}

Based on Table 4, $\mathrm{t}=-1.483, \mathrm{p}=0.142$, which is not significant at $\mathrm{p}<0.05$. Therefore Ho (2) which says that, there is no significant difference in in teachers' view on the learning experiences in KSSR Mathematics by gender was failed to be rejected. In conclusion, the level of teachers' agreement on the objectives of KSSR Mathematics is high and there is no significant difference in the level of agreement between male and female teachers on the learning experiences in KSSR Mathematics.

\section{Teachers' View on the Organization of Learning Experiences in KSSR Mathematics}

Research Question (c): How's teachers' view on the organization of learning experiences in KSSR Mathematics? 
Ho (3): There is no significant difference in teachers' view on the organization of learning experiences in KSSR Mathematics by gender.

To answer the research question (b) analysis was done descriptively by calculating the mean and standard deviation. The findings of the analysis are shown in Table 5.

Table 5 Teachers' View on the Learning Experiences in KSSR Mathematics

\begin{tabular}{lccc}
\hline Category of Respondents & No. & Mean Score & $\begin{array}{c}\text { Standard Deviation } \\
\text { (SD) }\end{array}$ \\
Male & 44 & 3.446 & 0.247 \\
Female & 48 & 3.458 & 0.237 \\
\hline Overall & 92 & 3.452 & 0.241 \\
\hline \multicolumn{2}{c}{$*$ 1 (Strongly Disagree), 2 (Disagree), 3 (Agree) and 4 (Strongly Agree) }
\end{tabular}

Result of the analysis is shown in Table 5. Based on the analysis, the level of teachers' agreement on the learning experiences in KSSR Mathematics is at the mean score $3.452(\mathrm{SD}=0.241)$. Analysis by gender shows that male teachers' agreement mean score is $3.446(\mathrm{SD}=0.247)$. Female teachers' agreement mean score is 3.458 $(\mathrm{SD}=0.237)$. Figure 4 shows box plots for the comparison of the mean score between male teachers' and female teachers' level of agreement on the organization of the learning experiences in KSSR Mathematics.

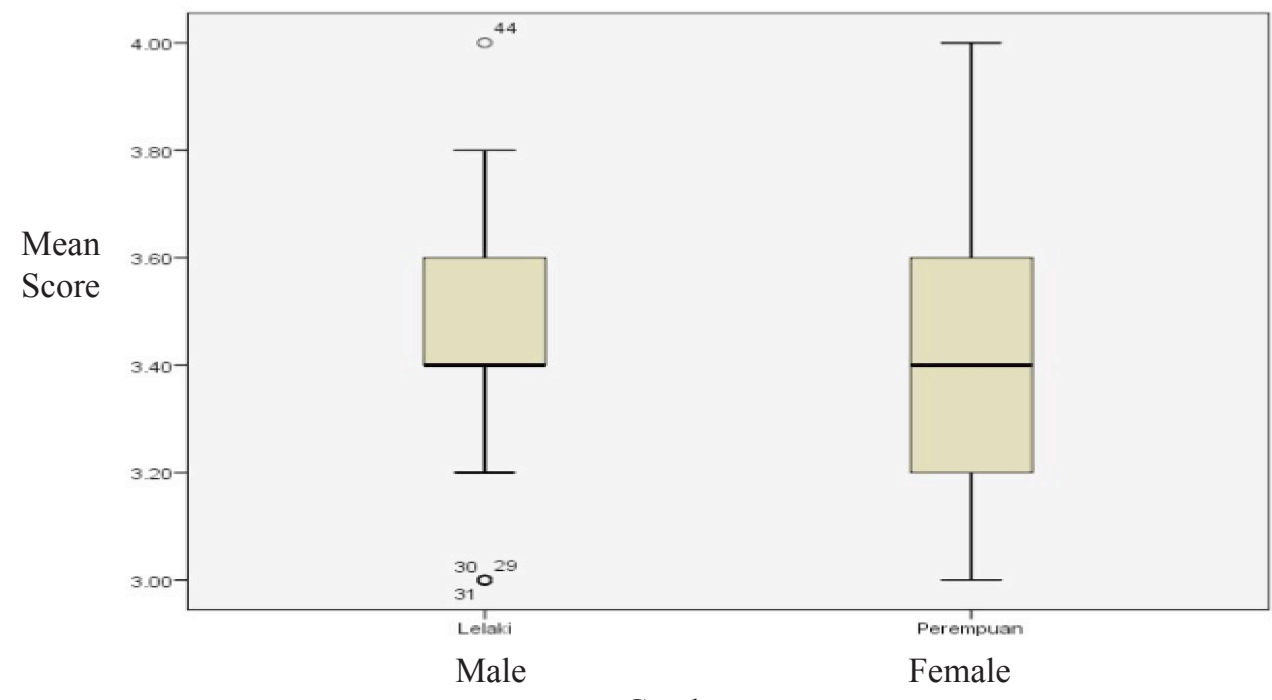

Gender

Figure 4 Mean Score Between Male Teachers' and Female Teachers' Level of Agreement on the Organization of the Learning Experiences in KSSR Mathematics.

To identify whether the difference of the mean scores between male and female teachers' agreement on the organization of the learning experiences in KSSR Mathematics is significant or otherwise, analysis was further done using t-test. Table 6 shows the result of the analysis. 
Table 6 Result of t-test on Mean Scores Between Male and Female Teachers' View on the Organization of the Learning Experiences in KSSR Mathematics.

\begin{tabular}{lcccc}
\hline & Levene Test & \multicolumn{4}{c}{ t-test for equality of means } & \\
\hline & Sig. & $\mathrm{t}$ & $\mathrm{df}$ & $\mathrm{P}$ \\
\hline $\begin{array}{l}\text { Equal variances assumed } \\
\begin{array}{l}\text { Equal variances not } \\
\text { assumed }\end{array}\end{array}$ & 0.947 & -0.255 & 90 & 0.799 \\
\hline
\end{tabular}

Based on Table $6, \mathrm{t}=-0.255, \mathrm{p}=0.799$, which is not significant at $\mathrm{p}<0.05$. Therefore Ho (3) which says that, there is no significant difference in in teachers' view on the organization of the learning experiences in KSSR Mathematics by gender was failed to be rejected. In conclusion, the level of teachers' agreement on the objectives of KSSR Mathematics is high and there is no significant difference in the level of agreement between male and female teachers on on the organization learning experiences in KSSR Mathematics.

\section{Teachers' View on the Assessment Used in KSSR Mathematics}

Research Question (d): How's teachers' view on the learning assessment used in KSSR Mathematics?

Ho (4): There is no significant difference in teachers' view on the learning assessment used in KSSR Mathematics by gender.

To answer the research question (d) analysis was done descriptively by calculating the mean and standard deviation. The findings of the analysis are shown in Table 7.

Table 7 Teachers' View on the Learning Assessment Used in KSSR Mathematics.

\begin{tabular}{lccc}
\hline Category of Respondents & No. & Mean Score & $\begin{array}{c}\text { Standard Deviation } \\
(\text { SD) }\end{array}$ \\
\hline Male & 44 & 3.355 & 0.289 \\
Female & 48 & 3.396 & 0.275 \\
\hline Overall & 92 & 3.376 & 0.281 \\
\hline \multicolumn{1}{c}{$*$ 1 (Strongly Disagree), 2 (Disagree), 3 (Agree) and 4 (Strongly Agree) }
\end{tabular}

Result of the analysis is shown in Table 7. Based on the analysis, the level of teachers' agreement on the learning assessment used in KSSR Mathematics is at the mean score $3.376(\mathrm{SD}=0.281)$. Analysis by gender shows that male teachers' agreement mean score is $3.355(\mathrm{SD}=0.289)$. Female teachers' agreement mean score is $3.396(\mathrm{SD}=0.275)$. Figure 5 shows box plots for the comparison of the mean score between male teachers' and female teachers' level of agreement on the learning assessment used in KSSR Mathematics. 


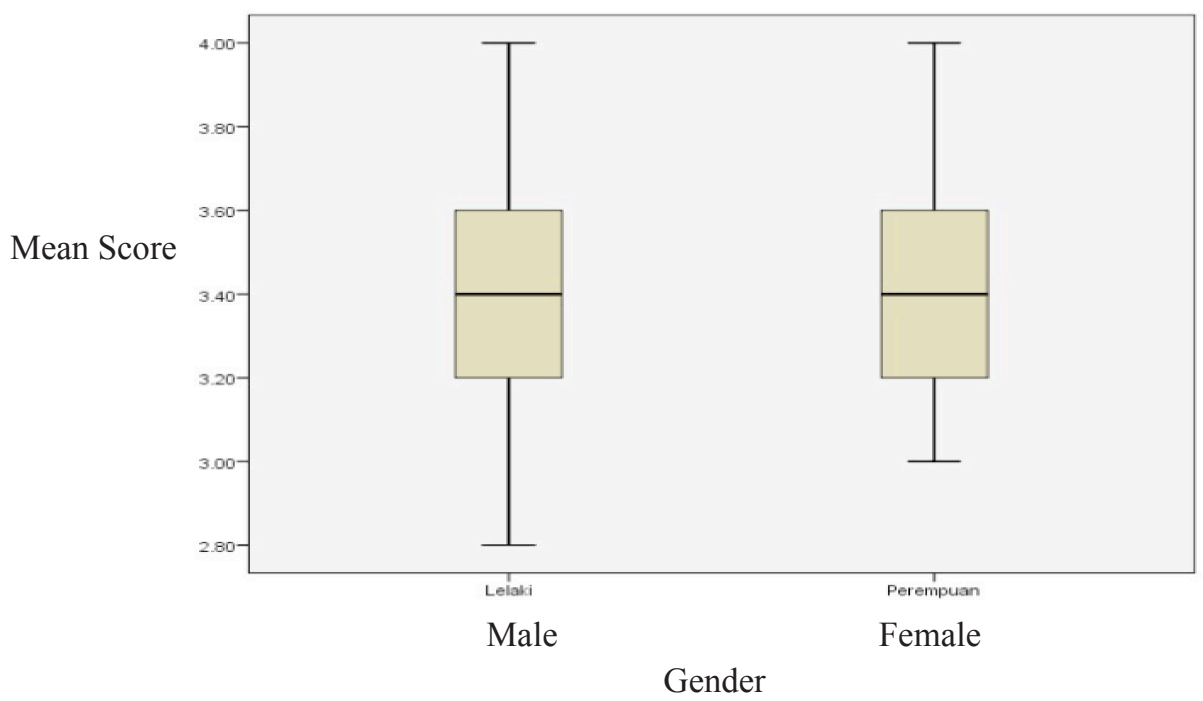

Figure 5 Mean Score Between Male Teachers' and Female Teachers' Level of Agreement on the Assessment Used in KSSR Mathematics.

To identify whether the difference of the mean scores between male and female teachers' agreement on the assessment used in KSSR Mathematics is significant or otherwise, analysis was further done using t-test. Table 8 shows the result of the analysis.

Table 8 Result of t-test on Mean Scores Between Male and Female Teachers' View on the Learning Assessment Used in KSSR Mathematics.

\begin{tabular}{lcccc}
\hline & Levene's Test & \multicolumn{1}{l}{ t-test for equality of means } & \\
\hline & Sig. & $\mathrm{t}$ & $\mathrm{Df}$ & $\mathrm{p}$ \\
\hline Equal variances assumed & 0.567 & -0.702 & 90 & 0.485 \\
$\begin{array}{l}\text { Equal variances not } \\
\text { assumed }\end{array}$ & & 0.567 & -0.702 & 90 \\
\hline
\end{tabular}

Based on Table $8, \mathrm{t}=-0.702, \mathrm{p}=0.485$, which is not significant at $\mathrm{p}<0.05$. Therefore Ho (4) which says that, there is no significant difference in in teachers' view on the learning assessment used in KSSR Mathematics by gender was failed to be rejected. In conclusion, the level of teachers' agreement on the objectives of KSSR Mathematics is high and there is no significant difference in the level of agreement between male and female teachers on on the learning assessment used in KSSR Mathematics.

\section{DISCUSSION AND CONCLUSION}

This study found that the level of teachers' agreement on KSSR Mathematics based on Document Standard of Curriculum given by Malaysia Ministry of Education is significantly high. Therefore, the curriculum of KSSR Mathematics is suitable for implementation in Malaysian primary schools. However any curriculum is dynamic in 
its nature, therefore changes on the curriculum can be happened over time and for the need of the situation (Ikhsan Othman \& Norila Md. Salleh, 2014). Reasonable KSSR Mathematics need to be monitored from time to time in order to always be relevant in its implementation. Dynamics curriculum should always be implemented in relevant with education goal for the development of Malaysian future generation (Malaysia Ministry of Education, 2013). It is recommended that studies involving a larger sample and involves various aspects of the curriculum should be done. In addition, this study is limited to KSSR Mathematics for level 1 of primary school involving Year 1, Year 2 and Year 3; therefore KSSR Mathematics studied in level 2 should also be studied for more accurate results.

\section{REFERENCES}

Abu Bakar Nordin \& Ikhsan Othman (2008). Falsafah Pendidikan dan Kurikulum. Tanjong Malim: Quantum Books.

Curriculum Development Centre (2010a). Dokumen Standard KSSR Matematik Tahun 1. Kuala Lumpur: Malaysia Ministry of Education.

Curriculum Development Centre (2010b). KSSR: Kurikulum Standard Sekolah Rendah. Kuala Lumpur: Malaysia Ministry of Education.

Curriculum Development Centre (2011). Dokumen Standard KSSR Matematik Tahun

2. Kuala Lumpur: Malaysia Ministry of Education.

Curriculum Development Centre (2012). Dokumen Standard KSSR Matematik Tahun

3. Kuala Lumpur: Malaysia Ministry of Education.

Ikhsan Othman \& Norila Md. Salleh. (2014). Aspek-aspek Dalam Kurikulum dan Pengajaran Sekolah Rendah. Tanjong Malim: Quantum Books.

Malaysia Ministry of Education (2010). Pelaksanaan Kurikulum Standard Sekolah Rendah (KSSR) Tahap Satu Mulai 2011. Surat Pekeliling Ikhtisas Bilangan 11 Tahun 2010 bertarikh 14 Oktober 2010.

Malaysia Ministry of Education (2011). Penambahbaikan Sistem Pentaksiran Kebangsaan Bagi Ujian Pencapaian Sekolah Rendah (UPSR) Mulai Tahun 2011. Pindaan Surat Pekeliling Lembaga Peperiksaan Bil. 1 Tahun 2011.

Malaysia Ministry of Education (2012). Malaysia Education Blueprint 2013-2025. Retrieved June 28, 2013, from http://www.moe.gov.my/userfiles/file/PPP/ Preliminary-Blueprint-Eng.pdf.

Malaysia Ministry of Education (2013). Pelan Pembangunan Pendidikan Malaysia 2013-2025). Laporan Ringkasan Eksekutif .

Tyler R.W. (1992). Prinsip Asas Kurikulum dan Pengajaran. Terjemahan Kamaruddin Hussin. Kuala Lumpur: Dewan Bahasa dan Pustaka. 